\title{
Study on The Effectiveness of Bilingual Learning in PBBI Program in Sekolah Tinggi Ilmu Pelayaran in 2019
}

\author{
Tristanti \\ Sekolah Tinggi Ilmu Pelayaran (STIP) Jakarta, Indonesia \\ Jl.Marunda-Makmur, Cilincing, Jakarta Utara - 14150, (021) 88991618 \\ e mail: tristantiagasta@yahoo.com
}

\begin{abstract}
Maritime Education Institutions need support and encouragement for the development of bilingual programs for cadets or seafarers in general in the future. So far, English, which is a foreign language in Indonesia, is still considered as a barrier to seafarers' communication on ships, especially on ships owned by foreign companies. The research design used in this study included mixed methods: quantitative surveys conducted on final semester of Nautical cadets, field observations and interviews with lecturers and the cadets. This study aims to explore the perceptions of the cadets and the lecturers about learning in English in relation to the bilingual teaching in the classroom. Some of the courses in the Nautical Study Program have been taught in English and Indonesian or bilingual. Some lecturers have an ability to teach bilingual and able to develop good methods of delivery so that the target of understanding the substance of learning materials can be met.
\end{abstract}

Keywords: Bilingual, Foreign Language, Learning Methods, Shipping Education

\section{Preliminary}

Students at maritime education institutions are prepared to enter a highly competitive and global job market. Graduates of this educational institution will compete with the human resources of seafarers and shipping industry players from various countries. Then, when they are accepted to work in the maritime industry, they often keep in contact with the languages and cultures of other foreign nations from various countries.

Until now, English has become the 'lingua franca' for the world of shipping which is increasingly open and 'borderless'. Therefore, mastery of English is one of the keys to opening job opportunities in this era, so teaching English is a demand in itself. Learning a foreign language (English) certainly requires practice, learning by doing. The habit of using it will encourage self-confidence to use a foreign language as a second language besides Mother Language and Indonesian. In our country, English is placed as the main foreign language taught in various secondary schools and universities in Indonesia based on the Decree of the Minister of Education No. 060 / U / 1993 dated 25 February 1993. To date, actually, there have been many developments in the curriculum and learning methods in teaching English, but in reality, it is very difficult for Indonesian learners to use English even in simple conversations.

The purpose of this study is to explore the perceptions of cadets and lecturers about learning in English in relation to the topic of bilingual or bilingual teaching in the classroom. Difficulties in delivering the substance of the material using English can be 
overcome when lecturers are able to develop interesting teaching methods. Considering that one of the "weaknesses" of seafaring school graduates in Indonesia to date is the ability to use English in communication.

Respondents in this study were 2 (two) classes of grade IV Nautical cadets and lecturers who teach their classes. Research data collection was carried out in 2019, which is a year since this program was launched out at STIP. It is hoped that this research will generate awareness and commitment to developing strategies in bilingual teaching. Thus the output or graduates of maritime education institutions in Indonesia will be more competitive, able to compete with sailors from other countries.

Theoretically, according to Prof. Dr. Singgih (2006) as he quoted from Mclaughlin, bilingualism can be interpreted as:

1. Code Switching, is the ability to change the current language into another language correctly. For example, children who are at school use English and then when they get home use Indonesian again.

2. Simultaneous language acquisition, is learning two languages simultaneously before the child is three years old

3. Successive language acquisition, is learning two foreign languages or a second language after the age of three years

\section{Methodology}

This research uses qualitative methods supported by numerical data from questionnaires and is descriptive in nature. Data collection was carried out by survey using questionnaires on cadets coupled with in-depth interviews with cadets and teaching lecturers. The research design used in this study included mixed methods: quantitative surveys conducted on final semester Nautical cadets, field observations and interviews with lecturers and cadets. The aim is to develop a conceptual framework based on current practice, which is expected to provide support and encouragement for the development of bilingual programs for cadets or sailors in general in the future. The research design and data collected are an attempt to answer the following research questions:

1. What are the perceptions of the lecturers and cadets in the implementation of the bilingual program?

2. What effective practices can be observed in bilingual classes? Is this practice in line with the linguistic achievements and course content that cadets must achieve?

3. How can the data collected be used to promote bilingual teaching and the future development of this program?

This research begins by constructing a printed survey (questionnaire) that asks final semester Nautical cadets to respond to questions directed to find out about responses to bilingual teaching practices and program perspectives. Following this, several lecturers in semester VIII were selected randomly and cadets in that semester were interviewed individually, one by one. For about a month, quantitative and qualitative data were collected. Quantitative data were collected from a Likert-style survey which was distributed to cadets. Open question responses and focused interviews with lecturers and cadets themselves, along with structured reflective written responses with cadets, which provided qualitative data. These interviews and reflective responses provide a narrative about bilingual teaching.

This paper is presented in The $4^{\text {th }}$ International Conference on Maritime Education and Training 233 


\section{Discussion}

English in Indonesia is commonly taught as a foreign language. The term of 'foreign language' in the field of language teaching is different from that of 'second language'. If it is considered as a foreign language, it is not used as a means of communication in certain countries where the language is taught, for example English in Indonesia. It is taught in school but is not used as a language to communicate in general in society. As for the second language, the language that is not the main language but is one of the languages commonly used in a country, for example English in Malaysia that is used as a second language. The mass media, communications and talks in the country often use English.

Meanwhile, foreign languages are usually taught as a subject in schools with the aim of basic communication and mastering 4 (four) language skills (listening, reading, writing, speaking) in that language within certain limits.

Learning is strived to be able to condition the learning environment so that it supports the changes that occur in students. Therefore, schools must equip their students with strategic abilities and skills (Arini, 2013). One of the abilities and skills is language or communication.

Arnyana (2008) states that in the bilingual learning process, one of the factors that greatly determines the implementation of this model is the lecturer [2]. In the bilingual learning process, every lecturer is required to have good mastery of subject matter and communication skills in English, besides that it is also stated that to be able to apply this learning model it is necessary for students who have a basic communication ability in English.

Bilingual education is a term that refers to teaching academic content in two languages, in this case Indonesian and English. How does bilingual education work? There are various programming models can be used in bilingual education. Historically, program models used for English Language Learners (ELL) have focused on helping students transition from their native language to English.

According to Chodijah (2000), the dual benefit of using a foreign language for students is that students can learn the language and at the same time the content of the lesson where each lecturer shows seriousness in teaching the learning process by using English as much as they can. It is indicated by the different frequency of use of English.

Bilingual education develops some important cognitive skills such as problem solving, logic, critical thinking and creativity because it exercises our brain and it forces us to think about how we can express and effectively convey our thoughts with the vocabulary we are familiar with in each language. These cognitive skills are transferable across disciplines and may even be one of the reasons why being bilingual helps to delay cognitive decline. These are also the same cognitive skills that experts and educators say are becoming more important to possess in order to successfully participate in our society and the workforce.

Meanwhile, on the other hand, we find that some lecturers who carry out learning using the language of instruction in English and bilingual realize that they are not confident in what they say in English. However, they feel confident that this courage will certainly have an impact on their students' motivation to develop the ability to use the language. The use of English as an introduction to learning will later be able to develop learning and at the same time improve language for students. However, the thing that needs to be considered here is the readiness of schools to implement it [6].

This paper is presented in The $4^{\text {th }}$ International Conference on Maritime Education and Training 234 
Until now, STIP cadets receive English language instruction in extracurricular activities after they study, at least 2 (two) times a week. In addition, there are also several other programs aimed at strengthening their ability to speak in English in public, namely through the English Speech activity in the Star Field (Lapangan Bintang) in the morning. These various activities aim to prepare cadets to have the ability, courage and confidence to speak both in a limited scope and in public in English.

In the mid-2018, on the instructions of the Principal of STIP, an English-Based Learning (PBBI) program was implemented. This program aims to encourage cadets and lecturers to be able to interact in English in the classroom to familiarize cadets with English. So, what about the preparation of teaching staff / lecturers in using English on campus? The campus needs to consider lecturers and cadets competence in English language.

\section{Presentation Of Data}

Respondents were asked several questions which were summarized as follows

\begin{tabular}{|r|l|r|r|r|r|r|}
\hline \multicolumn{1}{|c|}{ Questions } & \multicolumn{1}{c|}{ STS } & \multicolumn{1}{c|}{ TS } & \multicolumn{1}{c|}{ S } & \multicolumn{1}{c|}{ SS } & N \\
\hline 1 & Lecturers should use bilingual methods & 2 & 2 & 18 & 25 & 47 \\
\hline 2 & Lecturer is bilingual & 2 & 12 & 32 & 9 & 55 \\
\hline 3 & Lecturer - use bilingual- good and clear & 0 & 14 & 30 & 10 & 54 \\
\hline 4 & Lecturer - the presentation materials in English & 0 & 20 & 31 & 6 & 57 \\
\hline 5 & Cadet understands the lecturing well & 0 & 7 & 27 & 8 & 42 \\
\hline 6 & Source/ teaching materials should be in bilingual & 2 & 11 & 36 & 7 & 56 \\
\hline 7 & bilingual class raise motivation to speak English & 1 & 4 & 30 & 20 & 55 \\
\hline 8 & bilingual class will improve language skills & 1 & 1 & 27 & 26 & 55 \\
\hline 9 & Cadet likes speaking English & 5 & 3 & 26 & 20 & 54 \\
\hline & Accumulated Answers & 13 & 74 & 257 & 131 & \\
\hline
\end{tabular}

STS $=$ Very disagree

TS = Disagree

$\mathbf{S}=$ Agree

$\mathbf{S S}=$ Very agree

$\mathbf{N}=$ Number

Most of the lecturers of compulsory subjects today have actually been able to use several learning media / demonstrations, such as demonstrations, modelling, videos, the use of simulators and visuals. Vocabulary development is essential in most courses, and listening skills are developed more than speaking skills. Clarification and scaffolding support is provided when needed, and technology, such as TVs and laptops, is present in most classrooms and used though infrequently. But unfortunately, it is not often found that lecturers preview or activate the knowledge that has been taught before teaching the main lesson, the use of questions and higher / critical thinking activities, cadet-centred, group or working in pair, or hands on interactive activities. Most lessons / lectures still focus on listening, reading, and writing rather than speaking. Meanwhile, the essay questions about whether the suggestions and obstacles faced in bilingual learning are shown in the following table:

\section{Obstacles:}

1. Some cadets do not fully understand light vocabulary

2. Some cadets do not understand the use of English language

3. Need vocabulary enrichment 
4. Lack of practice

5. Need translation, interspersed with English language

6. Lecturers rarely enter, not keeping up with technological developments

7. Lecturers are not mastering the material well

For the question of who is a lecturer or which subject uses bilingual is shown in the following table:

Courses Delivered in bilingual languages:

1. Ship Stability

2. Physics

3. Arrangement / Handling Cargoes

4. Managing Ships

5. Maritime Law

6. Controls, Trim

7. Math

8. Terrestrial Navigation

9. Chemistry

10. Leadership- Work Ethics

The data is divided into two clusters, for the first cluster (about the lecturers' perception) :

\begin{tabular}{|r|l|r|r|r|r|r|}
\hline No. & \multicolumn{1}{|c|}{ Questions } & STS & TS & S & SS & N \\
\hline 1 & Lecturers should use bilingual methods & 2 & 2 & 18 & 25 & 47 \\
\hline 2 & Lecturer is bilingual & 2 & 12 & 32 & 9 & 55 \\
\hline 3 & Lecturer - use bilingual- good and clear & 0 & 14 & 30 & 10 & 54 \\
\hline 4 & Lecturer - the presentation materials in English & 0 & 20 & 31 & 6 & 57 \\
\hline
\end{tabular}

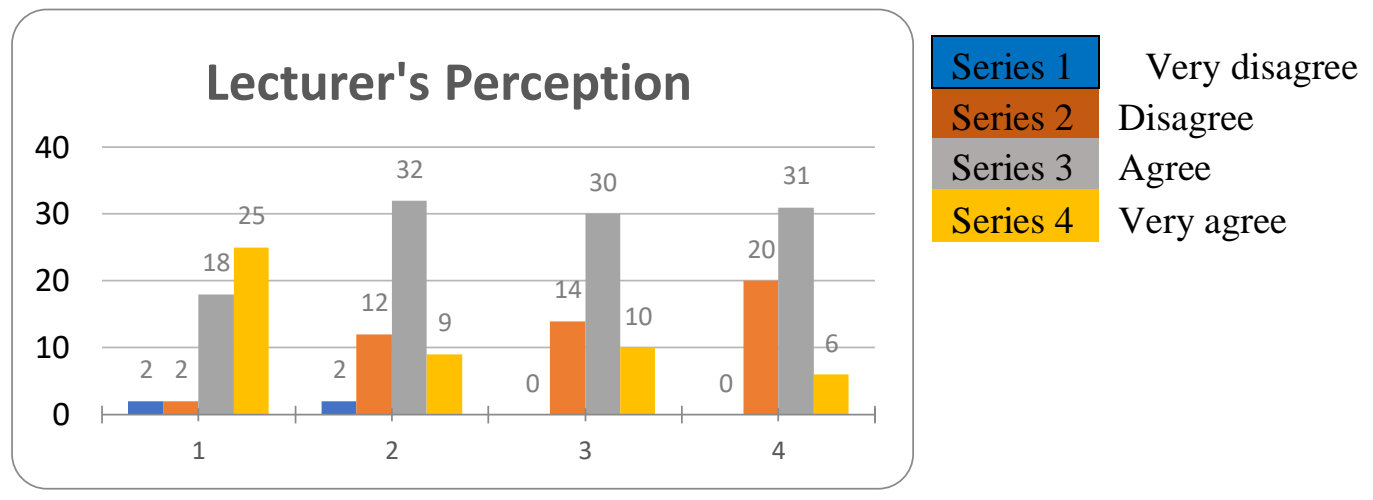

For 1 (one) month, the instructors we interviewed conveyed positive and negative responses to this program. We conducted random interviews with lecturers who especially taught in the last semester of Nautical class and their cadets. In one interview, several lecturers conveyed that the difficulty in the bilingual program was the lack of enthusiasm of cadets in class. According to them, teaching using Indonesian language is difficult for cadets to understand the lecturing, especially when using a foreign language. They do not deny that the cadets sometimes act passively in class, they only listen to the lecturers' explanations and do the assignments that are assigned to them. They do not want to be actively involved and think critically as expected by the lecturers.

Several lecturers were interviewed to obtain descriptions of their attitudes and perceptions. And what is interesting is the statement of several lecturers who respond this

This paper is presented in The $4^{\text {th }}$ International Conference on Maritime Education and Training 236 October $8^{\text {th }}, 2020$, Makassar, Indonesia 
bilingual program positively, that mastery of lecture content and communication in the bilingual language of instruction is needed by cadets to prepare them to face global competition at present and in the future. The teaching method is indeed one that plays an important role in the delivery of this bilingual teaching, so that lecturers are more active in two-way communication with cadets, provide word choices that are not too difficult for cadets to understand and be patient / slowly in giving explanations to cadets so that they do not hesitate when communicating in foreign languages.

Cadets who have participated in the bilingual program are requested to respond in writing towards reflective questions focused on their perceptions of benefits of being bilingual in the future, the success and challenges of having participated in the bilingual program, what they like and dislike during being involved in the bilingual program, the role and perceived usefulness and effectiveness of lecturers, and the future benefits of their participation in the bilingual program.

Some cadets conveyed their boredom since the lecturers' method of teaching are not interesting, so that they feel less motivated to be active in class. Less number of lecturers involve cadets actively and communicatively in class. They are sometimes reluctant to ask questions and only answer the lecturer's questions and they will be involved in the conversation if they are greeted by the lecturer. By this observation, we can say that actually lecturers can carry out bilingual teaching programs for cadets by giving them various method of teaching in English and the most important thing is continuously motivate the cadets about the importance of professionalism and bilingualism in the future.

The survey using Likert-scale include items that measure participants' beliefs, attitudes, and perceptions of lecturer roles, ongoing challenges and obstacles, and future goals. The survey includes items related to teaching practice and assessment, use of spoken and written language, development of language skills, perceived successes and gains in language and content, perceived challenges or difficulties, role and effectiveness of lecturers, and need for professional development.

Lecturers were mostly enthusiastic about their role in the bilingual program, although a few were less enthusiastic. Lecturers also see that teaching using the bilingual method is beneficial for the future in the world of shipping industry and is one of ways to prepare cadets to be competitive and to have good career in the global world.

Meanwhile for the second cluster (about cadets' perception):

\begin{tabular}{|r|l|r|r|r|r|r|}
\hline No. & \multicolumn{1}{|c|}{ Questions } & STS & TS & S & SS & N \\
\hline 1. & Cadet understands the lecturing well & 0 & 7 & 27 & 8 & 42 \\
\hline 2. & Source / teaching materials should be in bilingual & 2 & 11 & 36 & 7 & 56 \\
\hline 3. & Bilingual class raises motivation to speak English & 1 & 4 & 30 & 20 & 55 \\
\hline 4. & Bilingual class will improve language skills & 1 & 1 & 27 & 26 & 55 \\
\hline 5. & Cadet likes speaking English & 5 & 3 & 26 & 20 & 54 \\
\hline & & & & & & \\
\hline
\end{tabular}

This paper is presented in The $4^{\text {th }}$ International Conference on Maritime Education and Training 


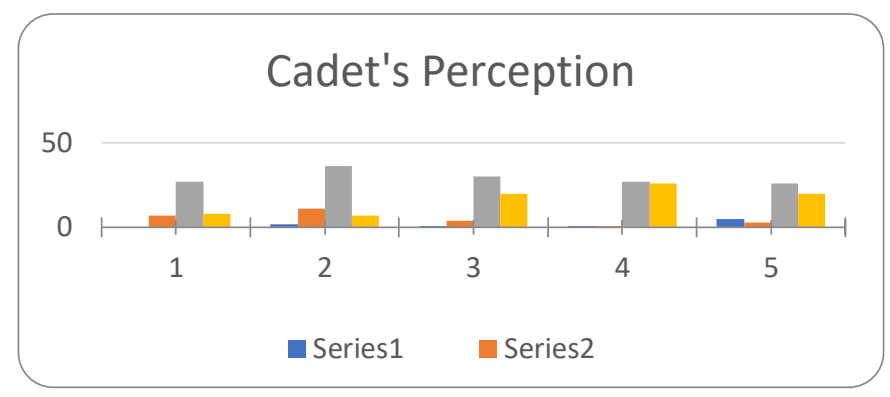

\begin{tabular}{|l|l} 
Series 1 & \multicolumn{1}{|l}{ Very disagree } \\
\hline Series 2 & Disagree \\
Series 3 & Agree \\
Series 4 & Very agree
\end{tabular}

The problem that is still quite prominent is the availability of teaching materials in English that will support the implementation of bilingual teaching. Some cadets are not quite understand the course material given in English though English is the pre requisites for cadets in STIP and they must achieve a significant level of proficiency in English. There needs to be a minimum level of linguistic competence where a student must be able to understand effectively in doing cognitive tasks. According to Cummins (2000) "Considerably less knowledge of language itself is usually required to function appropriately in interpersonal communicative situations than is required in academic situations", whereas academic language generally involves "much more low frequency vocabulary, complex grammatical structures, and greater demands on memory, analysis, and other cognitive processes" [4]. Arnyana (2008) states that in the bilingual learning process, one of the factors that greatly determines the implementation of this model is the lecturer, this model requires lecturers who have good mastery of material and communication skills in English, besides that to be able to apply this learning model it is necessary students who have a basic ability to communicate in English [2].

In general, cadets enjoy using English, are motivated to use English and believe that bilingual teaching has improved their English language skills. Cadets show that learning another language and being bilingual is important for them now and for their future. They realize the benefits of being bilingual and feel a sense of pride and comfort when speaking English, and some of them are not afraid to make mistakes. Most see themselves as adults who master a foreign language for the future, convinced that they will be better off later because of their participation in bilingual programs. They realize bilingualism as the key to acceptance in the maritime world community, future careers, better jobs and opportunities, increased competition and readiness, and greater profits and future choices.

English is as an important global language. The ability to communicate with others will increase the proficiency and understanding about many things, which also facilitate the intercultural relations and communication skills. If this bilingual program can be implemented more seriously and involve the entire STIP academic community, learning these vocabulary will be easier, and as a result, their vocabulary will be wider and richer, especially in shipping, technology, and communication skills. But unfortunately this program is still half-heartedly implemented so cadets and lecturers are less enthusiastic about it even though they know the benefits.

Personally, some cadets expressed a higher level of self-confidence, a level of comfort, a feeling of accomplishment and a sense of pride when being able to communicate and learn all subjects in a foreign language. They generally like their lecturers, think that their lecturers are very competent, and find classes more challenging. The positive adjectives that cadets use to describe their involvement in bilingual programs range from "happy, satisfied, interested, comfortable, and confident". 


\section{Conclusion And Recommendation}

\subsection{Conclusion}

1. Lecturers and cadets have a positive perception, that bilingual learning is important because of the demands of the work environment in the future but is still constrained by the limited capacity of lecturers and cadets in mastering English. Some of the courses have been taught in English or bilingual. Some lecturers have an ability to teach bilingual and can develop good methods of delivery so that the target of understanding the substance of learning materials can be met.

2. Most of the lecturers who teach in that semester have not used English as a means of communication in class. Some of those who carry out the bilingual program have difficulty in using vocabulary in accordance with the subjects such as the navigation or mathematics. In addition, there are several problems that arise in the field, for example, there is no learning module that is adapted to each course in English / bilingual, most evaluations are not in English, lack of serious support from the entire academic community.

\subsection{Recommendation}

1. The lecturer makes clear designs and fully developed concepts through FGDs or other academic forums related to English-based education. A concept that can be derived and operationalized.

2. Lecturers enrich learning materials or resources with bilingual learning videos. Audio visual content is very interesting and widely available on social media and educational sites. Learners can repeat the material according to their needs.

3. Classes need to be conditioned so that cadets as learners do not hesitate or are afraid to ask questions in the English used. Courage and self-confidence are important in using English.

4. Serious efforts from STIP are needed in overcoming the problem of lecturer weaknesses in using English actively, the campus needs to design English language training programs, send lecturers to English course institutions or collaborate with them to teach lecturers in STIP. In addition, it is important to increase the ability of cadets in English by the additional English language programs for them.

\section{References}

[1] Afrizal, 2015. "Metode Penelitian Kualitatif" Jakarta, PT. Raja Grafindo Persada.

[2] Arnyana, I. 2008. "Pengembangan Model Pembelajaran Dwi-bahasa Preview-Review Dipandu Strategi STAD dalam Pembelajaran Sains di SMA”. Jurnal Pendidikan dan Pengajaran UNDIKSHA

[3] Chotijah, I. 2000. "Kemampuan berbahasa Inggris anak dengan pembelajaran dwibahasa”. Jurnal Pendidikan Penabur

[4] Cummins, J. (2000). Language, power, and pedagogy: bilingual children in the Crossfire. Clevedon: Multilingual Matters.

[5] Gunarsa, Singgih D. 2006. "Dari Anak Sampai Usia Lanjut : Bunga Rampai Psikologi Perkembangan". Jakarta, Gunung Mulia.

[6] Muslich, M. 2010. Bahasa Indonesia pada Era Globalisasi. Jakarta: Bumi Aksara. 